\title{
Proses Konstruksi Indentitas Pembaca Karya Sastra Jawa di Kalangan Anak Muda Urban
}

\section{The Identity Construction Process of Readers of Jabanese Literature among Urban Young people}

\author{
Nur Qoni'atul Mushlihah \\ Departmen Ilmu Informasi dan Perpustakaan \\ Fakultas Ilmu Sosial dan Ilmu Politik, Universitas Airlangga \\ Nur.qoniatul.mushlihah-2015@ fisip.unair.ac.id
}

\begin{abstract}
Reading activity at this time is not interpreted as a physical activity that only involves visual elements, but also it is a cultural activitywhich includes the process of consumption and production, also its full meaning in it. Popular types of reading are increasingly developing in the community so that it discourages old readings such as Javanese literature. In the midst of the popular ones that is much favored by young people, there is a group of urban young people who are fond of Javanese literaturethat are considered ancient, serious, and heavy. Reading activities by young people not only produce meaning individually, but also form new cultural activities among fans of Javanese literature. The meanings generated by fans will be represented in life and form an identity. This qualitative study seeks to uncover the meaning and identity formed from the results of reading Javanese literatureby urban young people. This study uses ethnographic methods with a cultural studies perspective that focuses on qualitative exploration of reading activities as a cultural practice. With the help of Stuart Hall's Cultural Circuit theory, this study reveals how the meaning is done by urban young people various meanings and becomes a special identity that is identical from urban youth as readers of Javanese literature. This study shows five typologies of Javanese literary reader identity, that is Early Identity, Unconsistant Identity, Consistant Identity, Constructional Identity, Resistance Identity.
\end{abstract}

Keywords: construction of identity; urban youth; reading java literature; cultural studies; circuit of culture

\begin{abstract}
Abstrak
Aktifitas membaca saat ini tidak diartikan sebagai sebuah kegiatan fisik yang hanya melibatkan unsru-unsur visual saja, namun merupakan aktifitas budaya yang di dalamnya terjadi proses konsumsi dan produksi yang penuh dengan makna. Jenis bacaan populer semakin berkembang di masyarakat sehingga menyurutkan bacaanbacaan lama seperti sastra Jawa. Di tengah maraknya bacaan populer yang banyak digemari anak muda, terdapat sekelompok anak muda urban yang gemar terhadap bacaan karya sastra Jawa yang dinilai kuno, serius, dan berat. Aktifitas membaca yang dilakukan anak muda ini tidak hanya menghasilkan makna secara individual, namun membentuk aktifitas budaya baru di antara sesama penggemar karya sastra Jawa. Makna yang dihasilkan oleh penggemar akan direpresentasikan dalam kehidupan dan membentuk sebuah identitas. Studi kualitatif ini berusaha untuk mengungkap makna dan identitas yang terbentuk dari hasil membaca karya sastra Jawa oleh anak muda urban. Studi ini menggunakan metode etnografi dengan perspektif cultural studies yang terpusat pada eskplorasi kualitatif aktifitas membaca sebagai praktik kebudayaan. Dengan dibantu teori Sirkuit Budaya milik Stuart Hall studi ini mengungkap bagaimana pemaknaan yang dilakukan oleh anak muda urban
\end{abstract}


menghasilkan makna yang beragam dan menjadi identitas khusus yang identik dari anak muda urban sebagai pembaca karya sastra Jawa. Studi ini menghasilkan lima tipologi identitas pembaca karya sastra Jawa yaitu: Early Identity, Unconsistant Identity, Consistant Identity, Constructional Identity, Resistance Identity.

Kata Kunci: konstruksi identitas; membaca karya sastra Jawa; anak muda urban; cultural studies, sirkuit budaya

\section{Pendahuluan}

Dunia sastra dan budaya terus mengalami perkembangan di era modern ini. Munculnya berbagai jenis bacaan baru seperti novel, komik, cerpen berbentuk digital, dan lain-lain menjadi opsi bagi masyarakat luas untuk menikmati sebuah bacaan. Bacaan populer ditengah kemunculannya, bacaan-bacaan di era lampau seperti sastra di zaman kerajaan atau di era-era kemerdekaan menjadi sesuatu yang asing di kalangan masyarakat. Minimnya perpustakaan yang menyediakan atau toko buku yang menjual bacaan sastra di zaman kuno menjadi bukti bahwa minat masyarakat terhadap sastra lama semakin menurun setiap harinya. Sastra Jawa merupakan salah satu sastra lama yang kini mulai ditinggalkan oleh masyarakat. Anak muda urban merupakan salah satu kelompok yang menggemari bacaan populer. Meskipun banyak kelompok anak muda urban yang gemar dengan sastra-sastra populer, ternyata masih ada sekelompok anak muda yang gemar membaca sastra Jawa yang dinilai kuno dan tidak kekinian.

Di zaman modern ini sastra Jawa semakin kehilangan pamor. Atmowiloto salah seorang kritikus sastra Jawa bahkan pernah menyindir susutnya sastra Jawa dengan tulisannya yang berjudul “Kalaupun Sastra Jawa Berakhir, Apa Salahnya?” (Quinn, 1992). Tulisan tersebut merupakan respon dari banyaknya sastrawan Jawa yang beralih menulis sastra Indonesia yang memang lebih menjanjikan masa depan pengarang dari pada menulis sastra Jawa. Selain itu pembaca sastra Jawa juga seolah hilang bersamaan dengan makin hilangnya pengarang sastra Jawa. Pengarang sastra Jawa yang dianggap hanya menghasilkan karya rendahan dan minim nilai kehidupan menjadikan pembaca semakin tidak berselera terhadap sastra Jawa (Brata, 1981). Banyak pengamat yang menilai sastra Jawa semakin menurun kualitasnya karena ditulis demi tujuan hiburan belaka, bahkan beberapa karya banyak yang mengeksploitasi seks, sehingga dianggap memberikan dampak negatif terhadap kaum remaja (Suwondo, 2011). Bacaan populer semakin melejit dengan banyaknya penerbit yang mencetak karyakarya sastra baru. Hal tersebut dibuktikan dengan perbandingan terbitan antara bacaan populer dengan bacaan sastra, yakni bacaan populer diterbitkan 20 hingga 100 ribu jilid per dua atau tiga bulan, sedangkan bacaan sastra hanya diterbitkan seribu hingga duaribu per tahun (Probo, Vega dan Afrisia, 2015). Jumlah yang ditentukan oleh penerbit tersebut memang tidak dapat dilepaskan dari permintaan pasar yang semakin tinggi akan bacaan populer dan semakin rendah permintaannya terhadap sastra Jawa. Hal tersebut sudah dapat menjadi bukti rendahnya minat masyarakat terhadap sastra Jawa. 
Bacaan berupa sastra Jawa dan bacaan populer tentu berbeda baik dari segi konten maupun nilai yang diangkat. Seperti yang telah dijelaskan sebelumnya bacaan populer merupakan bacaan yang dikategorikan berdasarkan tingkat kepopulerannya. Biasanya bacaan yang dinobatkan sebagai bestseller menjadi idola bagi anak muda. Bacaan populer cenderung hanya dijadikan hiburan dengan ciri bacaan yang ringan dan penuh fantasi. Hal tersebut tentu berbeda dengan bacaan sastra Jawa yang cenderung berat dan serius. Selain itu nilai yang diangkat oleh sastra Jawa jauh berbeda dengan bacaan populer, yakni nilai-nilai adiluhung yang menjadikan sastra Jawa memiliki perbedaan tersendiri dibandingkan dengan bacaan lain. Bacaan populer seperti novel memang tidak jarang juga memberikan pesan dan nilai moral bagi para pembaca, namun yang membedakan dengan bacaan sastra Jawa ialah nilai kebudayaan Jawa yang luhur, filosofis, dan penuh makna, yang terselip di setiap karya-karya sastra Jawa yang tidak mungkin ditemukan dalam jenis bacaan lain.

Ketika membaca sastra Jawa pembaca diharuskan memahami bahasa Jawa secara utuh. Bahasa Jawa memiliki struktur dan tingkatan tersendiri, lain dengan bahasa Indonesia. Saat ini bahasa Jawa mulai ditinggalkan oleh orang Jawa sendiri, terutama anak muda. Suharyo (2018) menyebutkan bahwa generasi muda Jawa memiliki sikap negatif terhadap bahasa Jawa, mereka lebih banyak menggunakan bahasa Indonesia baik dalam ranah rumah maupun persahabatan. Bahasa Jawa yang semakin sulit dipahami anak muda juga menjadikan mereka malas membaca sastra Jawa karena tidak dapat langsung memahami maksud yang disampaikan dalam tulisan sastra Jawa. Pudarnya bahasa Jawa saat ini, masih ada anak muda urban yang mau membaca sastra Jawa. Kegemaran anak muda terhadap bacaan populer tidak terlepas dari fenomena budaya populer yang menyusup ke dalam ruang lingkup kehidupan anak muda.

Budaya populer sendiri memberikan dampak yang tidak sederhana terhadap kelangsungan kehidupan masyarakat dan sebuah generasi, bahkan ia mengancam budaya tradisional yang menjadi ciri khas suatu bangsa (Hosseini, 2010). Puslitbang Kemensos pernah merilis hasil riset di tahun 2015 yang menemukan bahwa anak muda Indonesia saat ini memiliki kecenderungan menjadi pengikut budaya luar, lunturnya sikap nasionalisme, idealisme, dan memudarnya pedoman moral di kalangan anak muda. Konsekuensi dari adanya globalisasi hingga masuknya budaya populer tidak dapat dihindari. Pada saat yang sama tidak dapat dibantah bahwa dominasi budaya populer akan mengganggu budaya lokal dan memungkinkan terjadinya pergolakan dalam sistem nilai, yang pada akhirnya akan terjadi krisis identitas di sebuah negara (Babran, 2008). Sebagai salah satu warisan budaya lokal, sastra Jawa turut menjadi salah satu elemen yang tergerus di kalangan anak muda akibat maraknya budaya populer. Sastra Jawa yang mengandung nilai-nilai sosial budaya Jawa yang adiluhung tidak lagi dijadikan pedoman bagi anak muda dalam bertindak dan berperilaku. Akibatnya saat ini terjadi krisis identitas yang melanda anak muda Indonesia.

Sekelompok anak muda urban yang gemar dengan sastra Jawa merupakan kelompok yang berusaha mempertahankan identitasnya dengan memahami budaya-budaya lokal Indonesia dan melestarikannya melalui sastra Jawa. Mereka justru memilih Sastra Jawa yang identik dengan bacaan 
yang berat, filosofis, dan syarat akan makna daripada membaca bacaan popular yang banyak diminati kaum muda. Tak hanya berhenti pada aktifitas membaca, mereka mendiskusikan hal-hal yang berkaitan dengan budaya Jawa. Diskusi inilah yang pada akhirnya membentuk pola pikir untuk mendapat sudut pandang yang benar dari dalam diri para pembaca, bukan menjadi pengikut budaya lain. Mereka memilah budaya baru yang masuk dalam kehidupannya sebelum benar-benar diaplikasikan dalam kegiatan keseharian. Anak muda urban yang tertarik dengan budaya kuno dan berusaha mempertahankan identitas lokalnya merupakan fenomena yang unik untuk diteliti. Pasalnya di tengah budaya populer yang terus menghantam kehidupan anak muda, dimana sebagian dari mereka memilih untuk mengikuti arusnya, anak muda penggemar karya Sastra Jawa ini lebih memilih mendalami budaya lokal melalui karya Sastra Jawa.

Melakukan aktifitas yang erat kaitannya dengan konsumsi dan produksi budaya jelas berbeda dengan aktifitas kekinian lainnya. Membutuhkan waktu dan penghayatan yang kuat agar aktifitas budaya ini dapat dimaknai oleh masing-masing individu karena di dalamnya terdapat kompleksitas bahasa yang tinggi. Jika dilihat dari segi bahasa, bahasa merupakan medium dari praktik-praktik budaya yang dapat menghasilkan makna (Barker, 2004). Menurut Hall (1997) bahasa dalam konsep budaya memiliki peran penting dalam proses konsumsi, produksi, serta merepresentasi makna dalam pembentukan suatu identitas. Demikian juga dengan bahasa yang ada di dalam karya Sastra Jawa. Bahasa yang dituangkan dalam karya sastra Jawa syarat akan makna dan setiap bagiannya mengandung makna kehidupan sekaligus budaya Jawa.

Penelitian ini tertarik untuk melihat aktifitas budaya dimana terjadi proses konstruksi identitas yang dilakukan anak muda urban ketika membaca karya sastra Jawa dan mendiskusikannya dalam sebuah kelompok. Mengungkap makna yang tidak tersampaikan dalam sebuah bahasa menjadi tugas dari cultural studies. Cultural studies memandang sebuah bahasa bukanlah media netral bagi pembentukan makna, tetapi merupakan bagian utama dari makna dan pengetahuan tersebut. Berdasarkan perspektif cultural studies aktifitas membaca dimaknai sebagai aktiftas budaya yang terbentuk dalam konteks sosial masyarakat. Konsep tentang teks bukan hanya menunjukkan kepada kata-kata tertulis, melainkan semua praktik yang memiliki makna (Barker, 2004: 11). Makna yang ingin disampaikan oleh penulis dapat saja ditangkap berbeda oleh pembaca berdasar pada pengalaman, pengetahuan, serta lingkungan dari pembaca. Stuart Hall (1997: 12) sebagai salah satu pemerhati kajian budaya menuturkan mengenai makna budaya yang terus diproduksi dan dikonsumsi dari aktifitas membaca yang bersamaan dengan berjalannya berbagai proses seperti adanya regulasi, pembentukan representasi, serta pembangunan identitas sebagai bagian dari sebuah sirkuit. Sirkuit yang dirumuskan oleh Hall merupakan sebuah perputaran budaya di mana terus terjadi proses pemaknaan tiada henti dari seorang pembaca dengan melibatkan konsumsi dan produksi secara terus menerus.

Penelitian mengenai sastra Jawa yang selama ini dilakukan masih terbatas dalam ranah ilmu kesastraan yang lebih banyak menggunakan pendekatan tekstual. Pendekatan tekstual hanya melihat 
makna sebuah karya sastra Jawa dari teks tertulis, mencoba mencari tau apa yang dibawa oleh penulis untuk disajikan kepada pembaca. Maka dari itu, penelitian ini mencoba mengetahui makna yang diciptakan oleh pembaca karya Sastra Jawa, melihat makna bukan secara tekstual tetapi sebagai aktifitas budaya. Anak muda yang selama ini diidentikkan dengan pengikut budaya populer nyatanya masih ada yang menggemari kebudayaan Jawa yang dinilai kuno, ketinggalan jaman, dan tidak cocok dengan arus globalisasi. Anak muda urban yang dengan segala ruang globalisasinya melalui bacaan Sastra Jawa mendalami nilai-nilai Jawa yang folosofis dan syarat akan makna. Fenomena inilah yang menarik peneliti untuk melihat apa yang terjadi pada anak muda urban pembaca karya sastra Jawa. Bagaimana makna yang dihasilkan dari proses membaca karya sastra Jawa? Dan bagaimana representasi dan identitas yang terbentuk dari proses membaca karya sastra Jawa oleh anak muda urban?

\section{Metode Penelitian}

Penelitian ini menggunakan metode penelitian kualitatif etnografis dengan perspektif cultural studies. Barker (2004: 10) menyatakan bahwa cultural studies etnografis terpusat pada eksplorasi tentang nilai dan makna dalam konteks cara hidup yaitu pertanyaan tentang kebudayaan, dunia kehidupan, dan identitas. Objek penelitian ini adalah anak muda urban pembaca karya sastra Jawa denga teknik penentuan informan menggunakan purposive sampling, di mana anak muda yang dijadikan informan harus memiliki kriteria tertentu yang telah ditentukan sebelumnya oleh peneliti, yakni antara lain: 1) Mereka merupakan anak muda yang tinggal dan menetap di Surabaya, 2) Anak muda yang pernah membaca lebih dari satu judul buku karya Sastra Jawa. Peneliti kemudian mengerucutkan karya Sastra Jawa yang muncul sebelum era modern yang merujuk pada buku Kasoesastran Djawi terbitan Kementerian Pengadjaran, Pendidikan, dan Keboedajaan, Djakarta: 1946, 3) Pernah melakukan diskusi dengan teman yang juga pernah membaca karya Sastra Jawa.

Dalam perspektif cultural studies anak muda diartikan tergantung konteks sosial serta budaya di mana anak muda itu berada. Hal ini berbeda dengan istilah yang digunakan untuk menamakan fase manusia dari anak-anak menuju dewasa (remaja) yang lebih melihat manusia dari segi pertumbuhan secara fisik dan usia. Sebagaimana didokumentasikan oleh Talcott Passon bahwa, anak muda merupakan suatu konstruk sosial yang tengah berubah yang muncul pada kurun waktu tertentu dan pada kondisi definitif (Barker, 2004: 334). Anak muda urban diartikan sebagai sekelompok anak muda yang hidup di lingkungan perkotaan di mana terjadi perkembangan ekonomi yang pesat, arus budaya yang silih berganti, dan globalisasi yang dengan cepat masuk ke dalam ruang lingkup kehidupan perkotaan. Dinamika kehidupan kota inilah yang turut mempengaruhi pembentukan identitas anak muda urban.

Kedua, aktifitas membaca jika ditinjau dari perspektif cultural studies berarti bahwa membaca tidak hanya sebagai kegiatan interaksi fisik antara manusia dan bacaan yang dibaca, 
melainkan terjadi proses dialektika di dalamnya sehingga disebut sebagai aktifitas budaya. Seperti yang dijelaskan oleh Barker (2004: 12) bahwa aktifitas membaca tidak hanya melibatkan unsur seperti kertas, meja, kursi, kaca mata tetapi terdapat proses dialektika di dalamnya. Ketika seseorang sedang menyerap sebuah bacaan, di saat itu pula ia sedang mengolah kembali apa yang ia dapat dari hasil membaca dan mengaitkannya dengan pengetahuan dan pengalaman yang tersimpan dalam memori, hal tersebut yang akan membentuk makna dari sebuah bacaan oleh pembaca. Makna tersebut tidak semata-mata berada di luar sana, melainkan dibangun oleh pembaca melalui tanda, khususnya tanda bahasa atau tanda hitam dalam teks (Barker, 2004: 8).

Pemaknaan sebagai hasil dari aktifitas membaca tidak dapat dilepaskan dari pengaruh sosiokultural. Sebuah teks bacaan memiliki sifat polisemis yang berarti bacaan tersebut memiliki banyak arti yang dapat diinterpretasikan oleh pembaca secara berbeda-beda. Pembentukan makna bukan semata-mata ditentukan dari teks yang ditulis oleh penulis, malah pembacalah yang sepenuhnya memiliki kuasa dalam memberikan makna pada sebuah teks. Lingkungan sosial yang melingkar di antara pembaca karya Sastra Jawa turut menyumbang makna-makna baru yang dibentuk dari aktifitas membaca. Senada dengan yang diungkapkan Cavallaro (2015: 94) bahwa membaca berlangsung pada konteks kultural tertentu, di mana interpretasi yang dihasilkan oleh pembaca sedikit banyak merupakan campur tangan suatu konteks tertentu yang didasarkan pada skema mental yang secara terus-menerus melalui proses pengenalan kepada individu, sehingga aktifitas membaca dibentuk oleh proses sosialisasi dan pemeliharaan dari persepsi. Dari sinilah dapat diketahui bahwa hasil dari aktifitas membaca dapat dimaknai secara berbeda-beda oleh tiap individu tergantung latar belakang dan pengalaman dari pembaca.

Ketiga, karya sastra merupakan hasil dari kebudayaan masyarakat. Sebagai teks budaya, karya sastra merepresentasikan masyarakatnya dan segala sistem yang melingkupinya: kekuasaan, nilai-nilai, kepentingan, kelas, ekonomi, politik, dan sebagainya (Purnomo, 2017:75). Dalam perspektif cultural studies karya sastra mengandung persoalan terutama representasi dan ideologi. Karya sastra, baik sebagai kreativitas estetis maupun respons kehidupan sosial, mencoba mengungkapkan perilaku manusia dalam suatu komunitas yang dianggap berarti bagi aspirasi kehidupan seniman, kehidupan manusia pada umumnya. Dari pernyataan tersebut dapat diketahui bahwa karya sastra selalu membawa maksud bagi pembacanya termasuk karya Sastra Jawa. Karya Sastra Jawa membawa nilai-nilai, kekuasaan, dan kepentingan, serta ideologi yang ingin disampaikan kepada pembaca.

Perspektif cultural studies memandang identitas tidak berdasarkan ikatan primordial sebuah suku atau karakteristik budaya universal yang dimiliki oleh kelompok tertentu, melainkan berdasarkan pembentukan sekat yang dikonstruksi dan dipelihara pada kondisi sosiohistoris tertentu (Suyanto dan Sutinah, 2011: 220). Salah satu sosiolog yang menggagas teori proses pembentukan identitas adalah Stuart Hall yang dengan teori sirkuit budayanya mengatakan bahwa pembentukan identitas 
merupakan proses yang terus berputar dan akan terus dimaknai berbeda sesuai dengan konteks sosial yang ada pada individu.

Aktifitas membaca yang akan menghasilkan pemaknaan sejatinya tidak serta merta dilatarbelakangi oleh pengalaman dan pengetahuan individu, namun lingkungan sekitar pembaca juga turut menyumbang makna apa yang akan dihasilkan oleh pembaca melalui aktifitas membaca. Sehingga secara tidak langsung lingkungan berupa komunitas atau kelompok tertentu mampu mendorong individu merangkai makna tertentu sesuai dengan yang diharapkan oleh lingkungan. Tuntutan lingkungan juga turut menjadi pertimbangan pembaca akan bacaan apa yang akan dikonsumsi. Anak muda urban yang hidup di lingkungan perkotaan dengan dinamika kebudayaan yang silih berganti dapat mempengaruhi makna yang akan dihasilkan. Adanya komunitas atau kelompok yang di dalamnya terjadi proses pertukaran makna juga akan menciptakan makna baru bagi pembaca. Makna yang telah dibagikan akan diproduksi kembali oleh sesama anggota kelompok dan sebaliknya makna yang telah didapat dari hasil interaksi dengan kelompok juga akan diproduksi kembali oleh pembaca, sehingga dalam kelompok atau komunitas ini terjadi proses reproduksi makna oleh masing-masing anggota di dalam dirinya sendiri.

Aktifitas budaya yang terjadi antar pembaca akan menciptakan sebuah sirkuit budaya yang di dalamnya mencakup proses konsumsi, produksi, regulasi, representasi, dan identitas. Sirkuit budaya disebut juga oleh Hall sebagai sebuah artikulasi. Ia menyebutnya demikian karena proses pemaknaan haruslah diekspresikan, mengalami perputaran, dan selalu memiliki hubungan satu dengan yang lain (Storey, 1996). Konsumsi dan produksi yang sebelumnya telah dilakukan oleh masing-masing individu akan direpresentasikan kepada lingkungan di sekitarnya. Representasi dan makna budaya memiliki materialitas tertentu, mereka melekat pada bunyi, prasasti, objek, citra, buku, majalah, dan program televisi, mereka diproduksi, ditampilkan, digunakan, dan dipahami dalam konteks sosial tertentu (Purnomo, 2017: 77). Menurut Hall (1997) sendiri sebagai pencetus teori sirkuit budaya mendefinisikan istilah representasi adalah sebagai sebuah bahasa untuk berkata tentang sesuatu yang bermakna bagi orang lain baik dalam bentuk tulisan, suara, musik. Representasi dari tiap individu inilah yang nantinya akan menjadi identitas tersendiri, yang khas dan berbeda. Identitas menjadi sesuatu yang melekat dalam diri individu sehingga menjadi tanda pengenal sebagai seseorang bagi orang lain. Representasi yang ditunjukkan oleh para pembaca sastra Jawa tidak lepas dari praktek regulasi yang di dalamnya mencakup unsur budaya. Oleh Hall regulasi diartikan sebagai sebuah sistem yang secara tidak langsung mengontrol aktifitas budaya yang terjadi antar anggota dalam sebuah kelompok malalui interaksi yang terjalin antar anggota. Pada saat yang sama para anggota juga melakukan proses konsumsi, produksi, dan secara tidak langsung terikat pada regulasi dalam sebuah kelompok. Interaksi yang dilakukan secara terus menerus maka akan memunculkan kebiasaan baru yang menjadi identitas kelompok yang unik, berbeda, dan menjadi ciri khas di antara mereka yang bukan anggota kelompok. 
Berdasarkan cultural studies, identitas dipandang sepenuhnya adalah konstruksi sosialbudaya, tidak ada identitas yang dapat 'mengada' (exist) diluar representasi atau akulturasi budaya (Sutrisno, in Bene, Putranto, 2007). Dari sinilah dapat diketahui identitas diri (self-identity) sesungguhnya lekat kaitannya dengan identitas sosial (socialidentity). Identitas seorang individu dapat dilihat dari kelompok mana ia berasal. Identitas kelompok terbagi menjadi empat, pertama, dalam populasi kelompok mereka mampu melestarikan kelangsungan kelompok dengan berkembang biak, artinya identitas seseorang ditentukan dari mana ia berasal dan dilahirkan, kedua, memiliki nilai-nilai budaya yang sama dan sadar akan rasa kebersamaannya dalam suatu bentuk budaya, ketiga, membentuk jaringan komunikasi dan interaksi sendiri, mereka berkumpul dan membangun sebuah komunikasi antar anggota kelompok, keempat, menentukan ciri kelompoknya sendiri yang diterima oleh kelompok lain dan dapat dibedakan dari kelompok populasi lain (Suyanto dan Sutinah, 2011: 218).

Identitas akhir-akhir ini tidak hanya terbatas pada suku, ras, dan etnis tertentu. Menurut pandangan postmodern gagasan mengenai identitas tidak semata-mata diartikan sebagai istilah yang absolut, tetapi sebagai politik representasi budaya. Representasi ini meliputi konstruksi dan penciptaan kembali secara terus menerus melalui penciptaan image dan naratif dalam teks visual dari budaya tinggi dan budaya populer. Identitas dapat dikatakan bahwa dibentuk (create) melalui upayaupaya aktif masyarakat untuk menggambarkan diri mereka atau merupakan hasil pembentukan diri dari dalam dan luar individu. Apabila dilihat dari pembagian identitas kelompok di atas kelompok pembaca karya Sastra Jawa termasuk ke dalam identitas dengan ciri kedua, ketiga, dan keempat, yakni menekankan pada ciri bahwa identitas kelompok pembaca karya sastra Jawa ada bukan dari proses perkembangbiakan manusia secara biologis, namun mereka berkembang secara sosial, mereka berinteraksi dan menjalin sebuah komunikasi hingga membentuk sebuah budaya yang melekat menjadi identitas.

Hubungan antara produksi, konsumsi, regulasi, representasi, dan identitas merupakan hubungan saling keterkaitan dan terus mengalami dinamika perubahan sesuai dengan konteks dan budaya yang melingkupinya. Budaya membaca sebagai sebuah bangunan sosial di sini dapat disejajarkan dengan konsep artikulasi, yang mengacu pada pembentukan kesatuan temporer antar sejumlah elemen yang tidak harus saling beriringan (Barker, 2004: 10). Dengan demikian, aktifitas membaca dikatakan 'diartikulasikan' lewat momen-momen produksi yang konsekuensinya dapat dilihat bagaimana produksi dituangkan dalam teks yang menjadi serangkaian praktik yang penuh makna. Sebuah teks selalu dikonstruksikan secara sosial dalam menghasilkan makna dan apa yang dilakukannya terhadap makna tersebut (seperti menciptakan identitas atau kesan) (Thwaites, Dacis, dan Mules, 2002). Dalam teori sirkuit budaya, identitas kultural pembaca karya Sastra Jawa merupakan proses yang selalu berputar, mereka mengonsumsi dan memproduksi makna karya Sastra Jawa yang kemudian merepresentasikannya dalam kelompok maupun kehidupan mereka secara luas, lalu terbentuk sebuah identitas yang melekat memiliki ciri tertentu, unik, dan khas. 


\section{Hasil dan Pembahasan}

\section{Ketertarikan Anak Muda Urban Terhadap Karya Sastra Jawa}

Secara umum ketertarikan anak muda urban terhadap karya sastra Jawa dipengaruhi oleh dua factor, yaitu faktor internal dan eksternal. Menurut Sugihartati (2012: 5) faktor internal merupakan dorongan yang berasal dari diri sendiri yang terbentuk dari adanya kebutuhan dan keinginan dalam diri individu yang harus dipenuhi. Faktor internal yang mempengaruhi anak muda untuk membaca karya sastra Jawa antara lain berasal dari kegemaran mereka menonton pagelaran wayang. Kebiasaan menonton sebuah cerita baik dari film maupun pertunjukan langsung akan menimbulkan rasa penasaran yang lebih jauh terhadap cerita tersebut, sehingga seseorang yang biasa menonton sebuah pertunjukan akan mencari informasi lebih lanjut mengenai kelanjutan cerita, salah satunya dengan membaca versi tulisnya (Aragoneses, 2014).

Selain karena rasa penasaran yang muncul setelah menonton wayang, anak muda lain menuturkan awal ketertarikannya dengan sastra Jawa karena menyukai hal-hal yang berkaitan dengan sejarah masa lalu. Bagi orang-orang yang memiliki ketertarikan dengan sejarah, membaca karya sastra dapat menjadi salah satu pilihan untuk menelisik sejarah dari sisi lain. Saryono (2009: 18) menjelaskan bahwa sastra mempunyai kemampuan untuk merekam semua pengalaman yang empirisnatural maupun pengalaman yang non-empiris supernatural, dengan kata lain sastra mampu menjadi saksi dan pengomentar kehidupan manusia.

Faktor selanjutnya yang mempengaruhi anak muda untuk membaca karya sastra Jawa adalah faktor eksternal yang diartikan sebagai kekuatan-kekuatan dari luar diri individu yang dapat mempengaruhi individu menentukan bacaannya (Sugihartati, 2012: 6). Faktor eksternal yang mempengaruhi anak muda untuk membaca karya sastra Jawa adalah faktor akademis. Ketika anak muda berada di lingkungan akademis yang berposisi sebagai pelajar maka akan mendapat tekanan dari pengajar untuk membaca bacaan tertentu untuk menunjang kegiatan pembelajaran. Keberlanjutan para pembaca untuk terus membaca sastra Jawa dipengaruhi oleh tujuan tertentu yang ingin dicapai, sehingga ketika sudah tidak ada dorongan dari luar anak muda ini tetap melanjutkan aktifitas membacanya.

Menurut teori sirkuit budaya, proses membaca terjadi secara berkelanjutan, antara proses satu dan lainnya yang saling mempengaruhi. Ketertarikan awal yang beragam dari para pembaca sastra Jawa nantinya akan mempengaruhi bagaimana mereka memaknai sastra Jawa nantinya.

\section{Pemaknaan Karya Sastra Jawa Oleh Anak Muda Urban Surabaya}

Para anak muda yang mengawali proses membaca dari faktor akademis dan memiliki tujuan tertentu ketika membaca sastra Jawa cenderung memaknai sastra Jawa sebagai bacaan yang digunakan untuk menambah wawasan, pengetahuan, serta sebagai alat yang digunakan untuk memenuhi tujuan mereka. Makna yang dihasilkan dari pembaca ini cenderung terbatas, yakni sesuai 
dengan tujuan mereka membaca. Para pembaca yang membaca karena memiliki tujuan memiliki pola konsumsi yang tidak konsisten. Mereka akan menghentikan aktifitas membacanya ketika merasa telah menemukan jawaban dari pertanyaannya, hal inilah yang menjadikan makna yang mereka dapat hanya terbatas dan tidak menyeluruh. Kegiatan membaca jenis ini dinamakan sebagai efferent reading, yakni pembaca yang melakukan aktifitas membaca dengan tujuan untuk menyelesaikan sebuah permasalahan (Sugihartati, 2012: 119). Kaitannya dalam hal reproduksi makna, pembaca jenis ini cenderung merefleksikan makna yang didapat sesuai dengan tujuan membaca sastra Jawa. Praktik reproduksi yang dilakukan oleh pembaca jenis ini juga tidak dilakukan secara konsisten. Mereka hanya melakukan reproduksi makna jika ada keinginan saja. Hal ini sesuai dengan yang diungkapkan oleh Rosenblatt (2007:5) bahwa orang yang membaca dengan maksud tertentu (efferent reading) hanya fokus untuk mempelajari apa yang diinginkannya, kemudian makna yang dihasilkan dari proses abstraksi dan analisis pembaca digunakan sebagai informasi dan petunjuk untuk melakukan sesuatu yang diinginkan oleh pembaca.

Makna selanjutnya yang berhasil dibentuk oleh anak muda pembaca karya sastra Jawa adalah sastra Jawa sebagai sebuah pengetahuan yang digunakan sebagai media untuk membentengi diri dari perbuatan yang melanggar norma dan penasihat diri. Pembaca senantiasa memaknai sastra Jawa dengan cara mengaitkannya pada latar belakang dan minat masing-masing pembaca, seperti pembaca yang berlatar belakang sejarah maka akan selalu mengaitkan sastra Jawa dengan fakta sejarah. Pembaca jenis ini membaca untuk kesenangan (reading for pleasure) tanpa adanya tujuan tertentu yang ingin dicapai. Menurut Ross (1999: 787) Pembaca yang melakukan kegiatan membaca untuk kesenangan akan menggunakan pengalaman hidupnya untuk memahami teks dan sebaliknya akan menggunakan teks untuk memahami kehidupan dalam berbagai situasi. Meski memiliki kedekatan yang intensif dengan sastra Jawa, pembaca jenis ini belum mampu menghasilkan karya baru dari proses konsumsi karena meyakini bahwa sastra Jawa tidak disusun dengan sembarangan, ia memiliki kaidah yang harus dipenuhi.

Makna selanjutnya yang berhasil dibentuk oleh anak muda pembaca karya sastra Jawa adalah sastra Jawa sebagai bacaan yang mampu memberikan petunjuk atas fenomena alam dan sosial yang terjadi di lingkungan pembaca melalui kode dan simbol yang diungkap oleh pembaca menurut versinya. Pembaca jenis ini berada pada tingkatan pembaca addict, ia bukan hanya mengisi waktu luangnya untuk membaca sastra Jawa, namun mengorbankan banyak waktu dan berusaha mencari waktu untuk melakukan aktifitas membaca sastra Jawa. Pembaca addict yang memiliki intensitas interaksi yang tinggi dengan bacaan sastra Jawa, membuat mereka tidak dapat lepas dari pengaruh sastra Jawa. Pembaca addict cenderung menggantungkan hidupnya terhadap sastra Jawa, sehingga hampir semua hal yang disampaikan dalam sastra Jawa berdampak terhadap pola pikir, gaya hidup, dan caranya dalam mengambil keputusan. Pembaca memposisikan sastra Jawa sebagai sesuatu yang sangat penting dalam kehidupannya sehingga sastra Jawa dijadikan pedoman dan penuntun jalan kehidupan layaknya kitab suci agama. Pembaca addict telah memiliki kemampuan untuk menciptakan 
karya baru sebagai hasil dari kegiatan membaca sastra Jawa yang berupa sastra Jawa modern, baik yang ditulis di kertas maupun lontar. hal ini sesuai dengan ungakapan dari Howard (2011: 47) yang menyebutkan bahwa pembaca addict yang membaca karena kesenangan akan memunculkan rasa pecaya diri dalam diri pembaca untuk menunjukkan skill yang ia miliki. Tidak hanya itu, pembaca juga menyebarluaskan sastra Jawa kepada masyarakat untuk megajak mereka menikmati sastra Jawa sekaligus meleketarikannya.

Makna terakhir yang berhasil dibentuk oleh anak muda pembaca karya sastra Jawa adalah sastra Jawa sebagai sebuah karya untuk melegitimasi kekuasaan kerajaan pada masa itu serta menganggapnya karya yang egois dan tertutup karena secara tidak langsung menggiring pembaca untuk menjadi manusia jawa dengan menolak budaya di luarnya. Pembaca jenis ini adalah pembaca kritis yang telah dibekali oleh makna yang sebelumnya telah tertanam dari lingkungannya. Sesuai dengan dengan pernyataan Cavallaro (2015:94) bahwa membaca adalah suatu aktifitas budaya yang berlangsung pada konteks kultural tertentu, di mana interpretasi yang dihasilkan oleh pembaca sedikit banyak merupakan campur tangan suatu konteks tertentu. Pada proses reproduksi pembaca jenis ini tidak menghasilkan karya sastra Jawa murni, melainkan menuangkan hasil konsumsi sastra Jawa ke dalam tulisan baru berupa esai.

\section{Representasi dan Identitas Anak Muda Urban Pembaca Karya Sastra Jawa}

Dalam kajian budaya representasi dan identitas merupakan dua hal yang tidak dapat dipisahkan. Barker (2004: 16) menegaskan bahwa identitas seseorang atau sebuah kelompok selalu diwujudkan melalui berbagai bentuk representasi yang dapat dikenali oleh diri sendiri maupun orang lain, sehingga identitas dapat dilihat melalui tandatanda, selera, sikap, gaya hidup, hingga kepercayaan. Representasi yang ditunjukkan oleh anak muda urban pembaca karya sastra Jawa tidak lepas dari makna yang berhasil didapat dari aktifitas membaca.

Pembentukan identitas dari anak muda urban pembaca sastra Jawa menghasilkan lima tipe pembaca, yakni: identitas pemula (early identity), identitas tidak tetap (unconsistant identity), identitas tetap (consistant identity), identitas terkonstruksi (constructional identity), dan identitas resisten (resistance identity). Early identity adalah pembaca pemula yang menggantungkan pola konsumsi membaca sastra Jawanya pada orang lain. Pembaca pada tipe ini cenderung mengalami kesulitan dalam membaca dan memahami karya sastra Jawa. Makna yang ditangkap oleh pembaca dari karya sastra Jawa sesuai dengan yang disampaikan oleh pengarang secara faktual dengan bahasa yang kasat mata. Unsur yang melekat dari aktifitas membaca sastra Jawa berupa unsur fisik, seperti tokoh, alur, cerita, dll. Anak muda dengan identitas pemula belum mampu menangkap makna dibalik sastra Jawa. Representasi yang ditunjukkan pada anak muda pembaca sastra Jawa tipe ini hanya terwujud berupa nilai-nilai universal di kehidupan sehari-hari. Kedua, Unconsistant Identity adalah pembaca karya sastra Jawa memiliki pola konsumsi yang tidak teratur. Konsumsi teks sastra Jawa dipengaruhi oleh tujuan-tujuan yang ingin dicapai ketika membaca sastra Jawa. Mereka yang berada 
pada tipe ini cenderung menghentikan bacaannya ketika telah menemukan tujuan yang dicapai ketika membaca. Makna yang ditangkap oleh pembaca tipe ini adalah terbatas. Nilai dan pesan yang disampaikan dalam sastra Jawa tidak dapat diserap secara utuh dan menyeluruh karena pembaca lebih fokus pada tujuan yang ingin ia dapatkan, sehingga ketika membaca sastra Jawa seringkali mengabaikan hal-hal tertentu yang bagi pembaca tidak dibutuhkan untuk menunjang tercapainya tujuan. Akibatnya, pembaca pada tipe ini menggantungkan jenis bacaan sastra Jawanya. Mereka cenderung membaca bacaan tertentu saja.

Ketidakkonsistenan pembaca pada jenis ini tidak hanya terlihat dari pola konsumsi, namun produksi dan representasi pembaca juga mengalami ketidakkonsistenan. Pembaca pada tipe ini memproduksi kembali makna yang mereka peroleh dari proses membaca sastra Jawa. Sama seperti proses konsumsi, mereka yang berada pada tipe ini juga menyesuaikan produksinya sesuai dengan tujuan membaca sastra Jawa seperti pembaca yang membaca sastra Jawa dengan tujuan untuk mempelajari tulisan aksara jawa, maka produksi yang dihasilkan berupa karya tulis aksara Jawa. Mereka yang berada pada tipe ini kesulitan untuk melakukan produksi makna dan menampakkan representasi, sehingga mereka tidak konsisten dalam menunjukkan identitas sebagai pembaca sastra Jawa. Selain identitas personal, para pembaca tipe ini juga membentuk identitas kelompok dengan bergabung pada komunitas pembaca sastra Jawa, namun mereka cenderung menjadi anggota pasif yang hanya sesekali mengikuti kegiatan komunitas.

Ketiga, consistant identity adalah pembaca yang mengawali kegemaran membaca sastra Jawa karena terdorong faktor internal, yakni karena rasa penasaran dengan sastra Jawa atau ketertarikan dengan hal-hal yang berkaitan dengan budaya jawa. Pembaca dengan identitas tetap memaknai sastra Jawa dengan cara mengaitkan nilai yang disampaikan dengan latar belakang masing-masing pembaca. Mereka merasa sastra Jawa memiliki kedekatan dengan kehidupan mereka. Posisi sastra Jawa yang penting dalam kehidupan mereka menjadikan pembaca ini konsisten dalam mengonsumsi, memproduksi, dan merepresentasikan makna sastra Jawa, sehingga identitas yang terbentukpun menjadi indentitas tetap yang tidak mudah berubah. Identitas tetap juga mereka tunjukkan melalui komunitas yang mereka ikuti. Anak muda pembaca sastra Jawa pada tipe ini belum mampu memproduksi kembali makna yang mereka dapat menjadi tulisan baru, mereka menganggap sastra Jawa tidak mudah untuk dituangkan dalam tulisan karena terpasung pada anggapan bahwa sastra Jawa adalah karya yang kaku dan memiliki kaidah yang sifatnya mengikat. Meski begitu mereka banyak merepresentasikan makna yang mereka peroleh melalui simbol dan atribut tertentu, seperti mengoleksi keris, gelang, atau menggunakan pakaian yang menyimbolkan diri sebagai manusia jawa. Nilai yang mereka peroleh dari membaca satsra jawa juga terinternalisasi yang mempengaruhi pembaca dalam menentukan tindakan.

Keempat, Constructional Identity adalah pembaca yang tidak hanya menjadikan aktifitas membaca sebagai aktifitas untuk mengisi waktu luang melainkan membaca sastra Jawa telah menggeser rutinitas lain. Pembaca addict melakukan pemaknaan dengan menyingkap kode atau 
simbol umum di dalam teks sastra Jawa. Pembaca ini melakukan kontekstualisasi makna dengan fenomena yang terjadi di sekitarnya. Pembaca pada tipe ini meyakini sastra Jawa selalu memberikan petunjuk atas hal-hal yang terjadi baik fenomena alam maupun sosial. Makna yang ditangkap pembaca bersifat subjektif sesuai dengan sudut pandang pembaca. Pembaca pada tipe ini tidak terbuka pada pemikiran di luar sastra Jawa, sehingga ia menolak bacaan-bacaan populer yang banyak digemari anak muda lain. Pembaca addict yang memiliki intensitas interaksi yang tinggi dengan bacaan sastra Jawa, membuat mereka tidak dapat lepas dari pengaruh sastra Jawa, mualai dari cara berbicara, berpakaian, bertindak, dan mengambil keputusan. Pembaca pada tipe ini sudah mampu menelurkan karya sastra Jawa hasil pemaknaan yang didapat dari aktifitas membaca, yang diwujudkan dalam bentuk puisi, prosa, cerkak, dan lain-lain. Selain itu pembaca pada tipe ini memiliki posisi yang penting dalam kelompoknya yang menunjang aktifitas membacanya.

Kelima, Resistance Identity adalah pembaca yang telah dibekali makna lain sebelum mengkonsumsi sastra Jawa. Pembaca tipe ini memiliki banyak alternatif makna untuk menerjemahkan simbol-simbol dalam teks sastra Jawa. Makna yang pembaca hasilkan dari membaca sastra Jawa dipengaruhi oleh berbagai hal, yakni lingkungan keluarga, organisasi, dan bahan bacaan lain yang ia baca selain sasatra jawa. Anak muda pada tipe resisten tidak hanya menangkap makna yang bersifat fisik atau yang terlihat secara langsung dari dalam teks. Mereka mampu mengungkap makna lain di balik sastra Jawa, seperti memaknai sastra Jawa sebagai sebuah karya yang egois, tertutup, jawa sentris, hingga pada makna sastra Jawa sebagai karya yang diciptakan bukan hanya untuk konsumsi pembaca melainkan sebagai bentuk legitimasi kekuasaan keraton pada masa itu. Pembaca pada tipe resisten, mampu memfilter nilai mana yang relevan dan tidak untuk dijadikan pedoman berperilaku di era modern ini. Pada tahap representasi anak muda ini tidak menunjukkan simbol yang khas selain daripada penuturan berbahasa. Sikapnya yang bebas dan rasional menghasilkan pemaknaan bahwa untuk menjadikan jawa sebagai identitas tidak perlu memakai benda-benda simbolis yang menunjukkan arti tertentu, namun inti dari itu semua adalah nilai yang terpatri dalam diri. Pembaca pada tipe ini lebih banyak memanfaatkan sastra Jawa sebagai sebuah ide dan gagasan, bukan simbolsimbol tertentu. Pembaca hanya memanfaatkan ide dan gagasan yang kemudian dituangkan dalam bentuk tulisan lain seperti esai. Pembaca tipe resisten mampu menjadikan sastra Jawa sebagai kacamata untuk melihat dunia yang serba modern, sekaligus mampu menempatkan pandangan modernitas ketika membaca sastra Jawa. 
Palimpsest: Journal of Information and Library Science Vol. 11, Issue 2, 2020, page 119-124

Tabel 1

Perbedaan Early Identity, Unconsistant Identity, Consistant Identity, Constructional Identity, dan Resistance Identity

\begin{tabular}{|c|c|c|c|c|c|}
\hline Aspek & Early Identity & $\begin{array}{c}\text { Unconsista nt } \\
\text { Identity }\end{array}$ & $\begin{array}{c}\text { Consistant } \\
\text { Identity }\end{array}$ & $\begin{array}{c}\text { Constructional } \\
\text { Identity }\end{array}$ & $\begin{array}{c}\text { Resistance } \\
\text { Identity }\end{array}$ \\
\hline $\begin{array}{l}\text { Ketertarika } \\
\text { n } \quad \text { dengan } \\
\text { sastra Jawa }\end{array}$ & $\begin{array}{l}\text { Aktifitas } \\
\text { membaca sastra } \\
\text { Jawa bermula } \\
\text { dari } \\
\text { faktor eksternal } \\
\text { (penyelesaian } \\
\text { tugas). } \\
\text { Keberlanjutan } \\
\text { membaca } \\
\text { sastra jawa } \\
\text { dipengaruhi } \\
\text { dorongan oleh } \\
\text { pihak luar, } \\
\text { namun pembaca } \\
\text { tetap } \\
\text { menikmati } \\
\text { aktifitas } \\
\text { membaca tanpa } \\
\text { merasa ada } \\
\text { tekanan karena } \\
\text { telah memiliki } \\
\text { kegemaran } \\
\text { membaca }\end{array}$ & $\begin{array}{l}\text { Aktifitas } \\
\text { membaca } \\
\text { sastra Jawa } \\
\text { bermula dari } \\
\text { faktor } \\
\text { eksternal. } \\
\text { Keberlanjut an } \\
\text { aktifitas } \\
\text { membaca } \\
\text { dipengaruhi } \\
\text { oleh tujuan } \\
\text { tertentu } \\
\text { yang ingin } \\
\text { dicapai ketika } \\
\text { sedang atau } \\
\text { usai } \\
\text { membaca } \\
\text { sastra Jawa. }\end{array}$ & \multicolumn{3}{|c|}{$\begin{array}{l}\text { Aktifitas membaca sastra Jawa bermula dari faktor internal } \\
\text { (rasa penasaran karena melihat tontonan wayang, penasaran } \\
\text { dengan sejarahnya, dll) }\end{array}$} \\
\hline & sejak dini. & & & & \\
\hline
\end{tabular}


Palimpsest: Journal of Information and Library Science Vol. 11, Issue 2, 2020, page 120-124

\begin{tabular}{|c|c|c|c|c|c|}
\hline & $\begin{array}{l}\text { Intensitas } \\
\text { membaca } \\
\text { kecil tergantung } \\
\text { dorongan yang } \\
\text { didapat } \\
\text { oleh pambaca }\end{array}$ & $\begin{array}{l}\text { Aktifitas } \\
\text { membaca } \\
\text { sastra Jawa } \\
\text { dilakukan } \\
\text { ketika ingin } \\
\text { mendapatka n } \\
\quad \text { tujua } \\
\text { n saja. Jenis } \\
\text { bacaan yang } \\
\text { dipilih juga } \\
\text { selalu } \\
\text { disesuaikan } \\
\text { dengan tujuan } \\
\text { pembaca } \\
\text { dalam } \\
\text { membaca } \\
\text { satra jawa. }\end{array}$ & $\begin{array}{l}\text { Aktifitas } \\
\text { membaca } \\
\text { dilakukan } \\
\text { untuk mengisi } \\
\text { waktu luang. }\end{array}$ & $\begin{array}{l}\text { Intensitas } \\
\text { membaca sangat } \\
\text { tinggi. Pembaca } \\
\text { termasuk } \\
\text { sebagai } \\
\text { pembaca yang } \\
\text { addict, yakni } \\
\text { pembaca yang } \\
\text { mengorbankan } \\
\text { waktu dan } \\
\text { rutinitasnya } \\
\text { untuk membaca } \\
\text { sastra Jawa. }\end{array}$ & $\begin{array}{l}\text { Aktifitas } \\
\text { membaca } \\
\text { dilakukan untuk } \\
\text { mengisi waktu } \\
\text { luang. }\end{array}$ \\
\hline konsumsi & $\begin{array}{l}\text { Memaknai } \\
\text { sastra Jawa } \\
\text { sebagai karya } \\
\text { untuk } \\
\text { menambah } \\
\text { pengetahuan } \\
\text { dan } \\
\text { memperluas } \\
\text { wawasan. } \\
\text { Unsur-unsur } \\
\text { fisik menjadi } \\
\text { hal yang } \\
\text { melekat dalam } \\
\text { diri pembaca } \\
\text { ketika } \\
\text { membaca sastra } \\
\text { seperti tokoh, } \\
\text { alur cerita, dll. }\end{array}$ & $\begin{array}{l}\text { Memaknai } \\
\text { sastra Jawa } \\
\text { sebagai karya } \\
\text { yang berguna } \\
\text { untuk } \\
\text { mencapai } \\
\text { tujuantujuan } \\
\text { pembaca. } \\
\text { Nilai yang } \\
\text { disampaikan } \\
\text { pengarang } \\
\text { tidak } \\
\text { mampu } \\
\text { ditangkap } \\
\text { secara utuh } \\
\text { karena } \\
\text { pembaca } \\
\text { hanya fokus } \\
\text { pada tujuan } \\
\text { membaca } \\
\text { sastra Jawa. }\end{array}$ & $\begin{array}{l}\text { Memakai sastra } \\
\text { jawa } \\
\text { sebagai sebuah } \\
\text { media untuk } \\
\text { membentengi } \\
\text { diri dari } \\
\text { perbuatan yang } \\
\text { melanggar } \\
\text { norma dan } \\
\text { penasihat diri. } \\
\text { Pembaca } \\
\text { senantiasa } \\
\text { memaknai } \\
\text { sastra jawa } \\
\text { dengan cara } \\
\text { mengaitkann ya } \\
\text { pada latar } \\
\text { belakang dan } \\
\text { minat } \\
\text { masingmasing } \\
\text { pembaca, } \\
\text { seperti } \\
\text { pembaca }\end{array}$ & 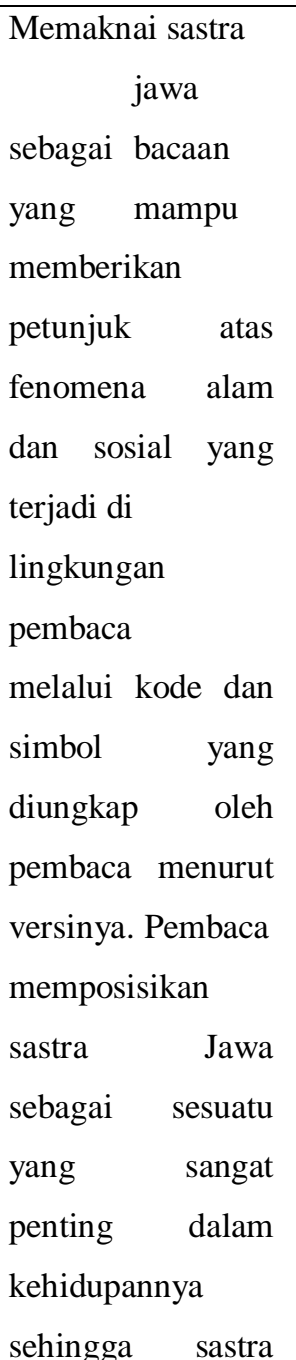 & $\begin{array}{l}\text { Pembaca mampu } \\
\text { menangkap } \\
\text { makna lain di } \\
\text { balik } \\
\text { penyusunan } \\
\text { sastra Jawa. } \\
\text { Pembaca } \\
\text { termasuk } \\
\text { sebagai pembaca } \\
\text { yang kritis } \\
\quad \text { yang } \\
\text { memaknai } \\
\text { sastra jawa } \\
\text { sebagai sebuah } \\
\text { karya untuk } \\
\text { melegitimasi } \\
\text { kekuasaan } \\
\text { kerajaan pada } \\
\text { masa itu. } \\
\text { Selain itu sastra } \\
\text { dianggap sebagai } \\
\text { karya }\end{array}$ \\
\hline
\end{tabular}


Palimpsest: Journal of Information and Library Science Vol. 11, Issue 2, 2020, page 121-124

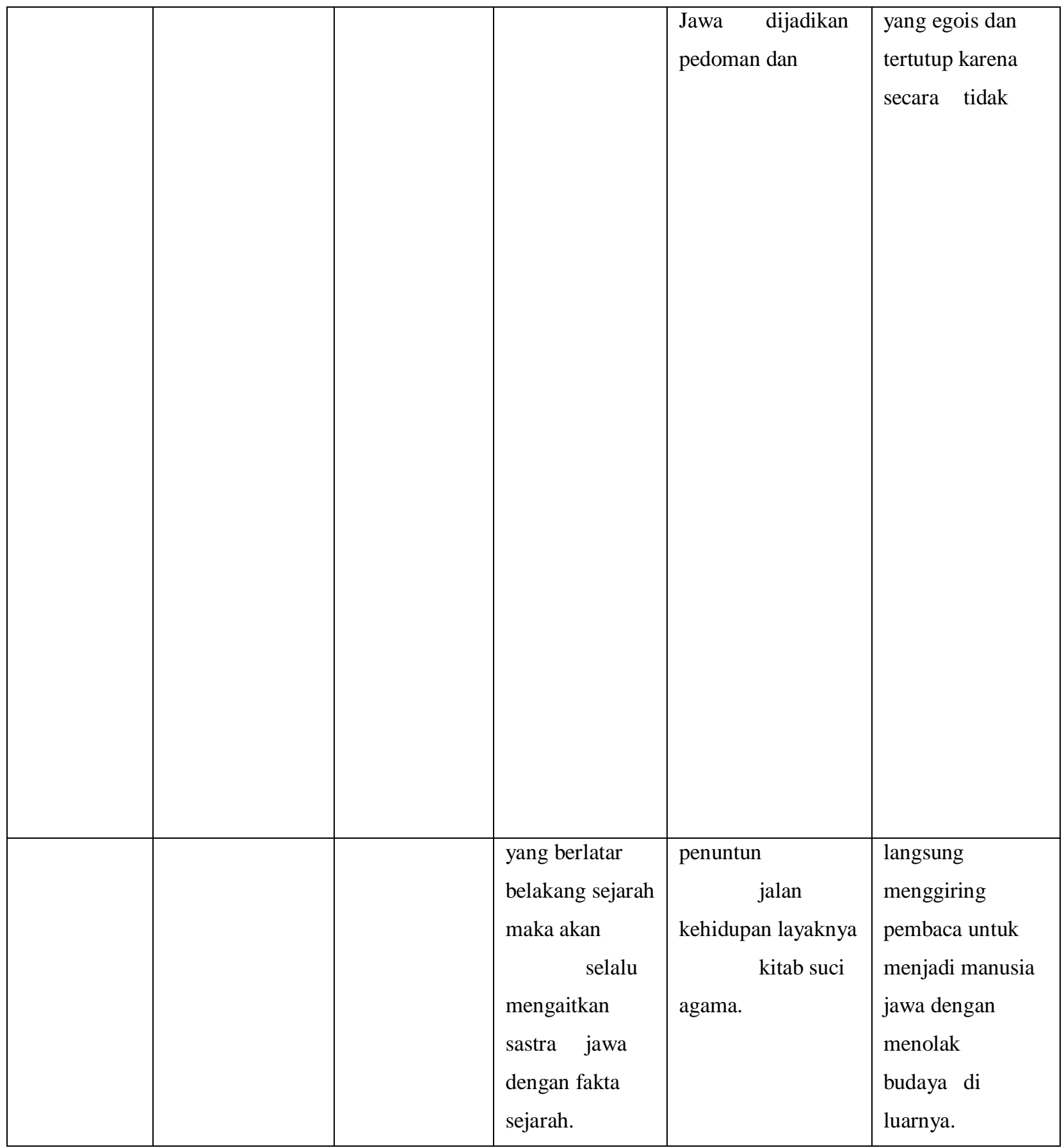


Palimpsest: Journal of Information and Library Science Vol. 11, Issue 2, 2020, page 122-124

\begin{tabular}{|c|c|c|c|c|c|}
\hline Produksi & $\begin{array}{l}\text { Memproduksi } \\
\text { makna sastra } \\
\text { Jawa menjadi } \\
\text { sebuah karya } \\
\text { sastra baru, } \\
\text { namun harus } \\
\text { dengan dorongan } \\
\text { dari pihak luar. }\end{array}$ & $\begin{array}{l}\text { Mampu } \\
\text { menghasilka } \\
\mathrm{n} \quad \text { sebuah } \\
\text { karya baru } \\
\text { dari proses } \\
\text { konsumsi, } \\
\text { namun } \\
\text { mengalami } \\
\text { kesulitan } \\
\text { ketika } \\
\text { memproduk si } \\
\text { makna sastra } \\
\text { Jawa, sehingga } \\
\text { produksi tidak } \\
\text { dilakukan } \\
\text { secara } \\
\text { konsisiten. }\end{array}$ & $\begin{array}{l}\text { Belum mampu } \\
\text { menghasilka n } \\
\text { karya baru dari } \\
\text { proses } \\
\text { konsumsi } \\
\text { karena } \\
\text { meyakini } \\
\text { bahwa sastra } \\
\text { Jawa tidak } \\
\text { disusun dengan } \\
\text { sembarangan, } \\
\text { ia memiliki } \\
\text { kaidah yang } \\
\text { harus dipenuhi. }\end{array}$ & $\begin{array}{l}\text { Menciptakan } \\
\text { karya baru sebagai } \\
\text { hasil dari kegiatan } \\
\text { membaca sastra } \\
\text { Jawa yang berupa } \\
\text { sastra Jawa } \\
\text { modern, baik yang } \\
\text { ditulis di kertas } \\
\text { maupun lontar. } \\
\text { Menyebarluaska n } \\
\text { sastra Jawa } \\
\text { kepada masyarakat } \\
\text { untuk megajak } \\
\text { mereka } \\
\text { menikmati } \\
\text { sastra Jawa } \\
\text { sekaligus } \\
\text { membantu } \\
\text { melekstarikannya. }\end{array}$ & $\begin{array}{l}\text { Tidak } \\
\text { menghasilkan } \\
\text { karya sastra Jawa } \\
\text { murni, melainkan } \\
\text { menuangkan } \\
\text { hasil konsumsi } \\
\text { sastra Jawa ke } \\
\text { dalam tulisan } \\
\text { baru berupa esai. }\end{array}$ \\
\hline $\begin{array}{l}\text { Representa } \\
\text { si }\end{array}$ & $\begin{array}{l}\text { Tidak } \\
\text { menunjukkan } \\
\text { simbol melalui } \\
\text { atribut tertentu, } \\
\text { namun } \\
\text { menangkap } \\
\text { nilai yang } \\
\text { disampaikan } \\
\text { dalam sastra } \\
\text { Jawa dan } \\
\text { mereflesikann } \\
\text { ya dalam } \\
\text { kehidupan } \\
\text { sehari-hari. }\end{array}$ & $\begin{array}{l}\text { Representas } \\
\text { i yang } \\
\text { ditunjukkan } \\
\text { sesuai dengan } \\
\text { tujuan } \\
\text { pembaca } \\
\text { dalam } \\
\text { membaca } \\
\text { sastra Jawa, } \\
\text { seperti } \\
\text { menerapkan } \\
\text { wirid jawa. } \\
\text { Selain itu, } \\
\text { representasi } \\
\text { tidak } \\
\text { ditunjukkan } \\
\text { secara } \\
\text { konsisten. }\end{array}$ & $\begin{array}{l}\text { Menunjukkan } \\
\text { simbol sebagai } \\
\text { pembaca sastra } \\
\qquad \text { jawa } \\
\text { melalui atribut } \\
\text { tertentu } \\
\text { sekaligus } \\
\text { menciptakan } \\
\text { budaya baru } \\
\text { bersama } \\
\text { pembaca sastra } \\
\text { lain. jawa }\end{array}$ & 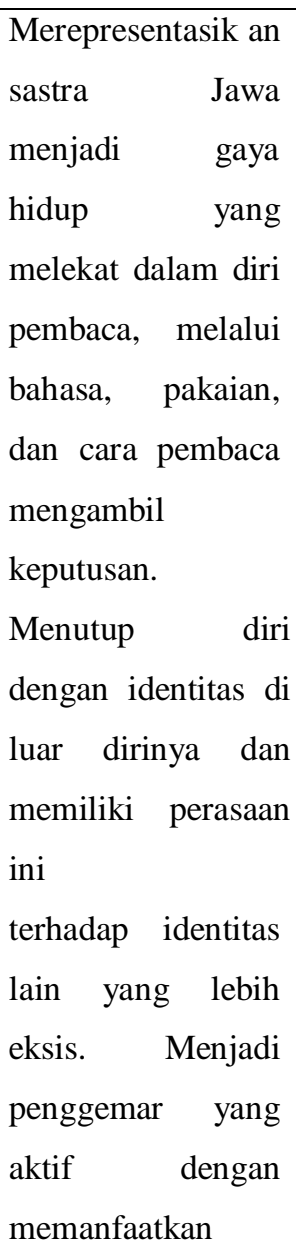 & $\begin{array}{l}\text { Tidak secara } \\
\text { simbolis } \\
\text { merepresentasi ka } \\
\text { sastra Jawa } \\
\text { melalui atribut } \\
\text { tertentu, } \\
\text { melainkan } \\
\text { dengan } \\
\text { menyerap nilai } \\
\text { adiluhung untuk } \\
\text { dijadikan } \\
\text { sebagai } \\
\text { pedoman dalam } \\
\text { norma } \\
\text { kehidupan. } \\
\text { Menjadikan } \\
\text { sastra Jawa } \\
\text { sebagai kacamata } \\
\text { dalam } \\
\text { memandang } \\
\text { modernitas }\end{array}$ \\
\hline
\end{tabular}


Palimpsest: Journal of Information and Library Science Vol. 11, Issue 2, 2020, page 123-124

\begin{tabular}{|l|l|l|l|l|}
\hline & & & sumber daya yang & sekaligus \\
dimiliki untuk & menggunakan \\
mobilisasi & & kacamata modern \\
komunitas sastra & untuk melihat \\
sisi lain \\
dalam \\
\end{tabular}

\section{Simpulan}

Berdasarkan temuan dan analisis yang telah dilakukan dapat disimpulkan bahwa makna yang dihasilkan anak muda pembaca sastra Jawa adalah beragam yang tidak ditentukan oleh teks yang diciptakan oleh pengarang, namun dibentuk sendiri oleh pembaca. Ketertarikan anak muda urban terhadap bacaan karya sastra Jawa memiliki latar belakang yang berbeda-beda hal ini menunjukkan bahwa aktifitas membaca bukan aktifitas sederhana yang melihat faktor fisik, namun membaca karya sastra Jawa adalah aktifitas budaya. Kemudian, Sirkuit budaya merupakan sebuah proses yang terus berulang dan saling berkaitan. Aktifitas membaca yang dilakukan oleh pembaca karya sastra Jawa tidak hanya menghasilkan makna yang beragam, namun pada akhirnya juga menghasilkan identitas yang beragam. Setiap proses dalam sirkuit budaya yang terdiri dari konsumsi-produksi-regulasi-representasiidentitas selalu memiliki keterkaitan. Bagaimana anak muda urban memaknai sastra Jawa berhubungan dengan bagaimana nantinya mereka merepresentasikan makna yang telah didapat. Representasi yang ditunjukkan oleh anak muda urban pembaca karya sastra Jawa menghasilkan identitas yang melekat dalam diri pembaca. Seberapa kuat representasi yang ditunjukkan para pembaca semakin menguatkan identitas yang secara bersamaan dibentuk lewat representasi.

\section{Daftar Pustaka}

Babran, Sedigheh. 2008. Media, Globalization of Culture, and Identity Crisis in Developing Countries. (Intercultural Communication Studies XVII: 2)

Barker, Chris. 2004. Cultural Studies: Teori dan Praktik. Yogyakarta: Kreasi Wacana. Brata, Suparto. 1981. Jatuh Bangung Bersama Sastra Jawa. Jakarta: Proyek Penulisan dan Penerbitan Buku/Majalah Pendidikan Pengetahuan Umum dan Profesi.

Cavallaro, Dani. 2015. Arena Produksi Kultural: Sebuah Kajian Sosiologi Budaya. Bantul: Kreasi Wacana. 
Palimpsest: Journal of Information and Library Science Vol. 11, Issue 2, 2020, page 124-124

Hall, Stuart (Ed). 1997. Representation: Cultural Representations and Signifying Practice. London: Sage Publication.

Hosseini, Hossein. 2010. Popular Culture In Asia: Globalization, Regionalization, and Localization.

(Science Direct Publication, Procedia, Journal Social and Behavioral Science 2, pg 735675358)

Purnomo, Mulyo Hadi. 2017. Menguak Budaya dalam Karya Sastra: Antara Kajian Sastra dan Budaya. (Endogami: Jurnal Kajian Ilmu Antropologi)

Probo, Vega dan Rizky Sekar Afrisia. 2015. Penjualan Buku Agama dan Anak Kalahkan Novel. Cnn Indonesia (6 Juli 2019)

Quinn, George. 1992. The novel in Javannese. Leiden: KITLV.

Suwondo, Tirto. 2011. Sastra Jawa dan Sistem Komunikasi Modern. Yogyakarta: Gama Media

Storey, John. 1996. What Is Cultural Studies? A Reader. New York: Oxford University Press.

Sutrisno, Mudji, in Bene, Hendar Putranto. 2007. Cultural Studies: Tantangan bagi Teori-Teori Besar Kebudayaan. Depok: Koekoesan

Suyanto, Bagong dan Sutinah. 2011. Metode Penelitian Sosial: Berbagai Alternatif Pendekatan (Edisi Revisi). Jakarta: Kencana.

Thwaites, Tony., Lloyd Davis, dan Warwick Mules. 2002. Introduction Cultural and Media Studies: Sebuah Pendekatan Semiotik. Yogyakarta: Jalasutra. 